\title{
Correction to: Assessing the potential of biochar aged by humic substances to enhance plant growth and soil biological activity
}

Tereza Hammerschmiedt ${ }^{1,2}$, Jiri Holatko ${ }^{1}$, Vaclav Pecina ${ }^{1,3}$, Dalibor Huska ${ }^{4}$, Oldrich Latal ${ }^{1}$, Antonin Kintl ${ }^{1,5}$, Maja Radziemska 1,6, Sadiq Muhammad ${ }^{7}$, Zygmunt M. Gusiatin ${ }^{8}$, Martina Kolackova ${ }^{4}$, Muhammad Nasir ${ }^{9}$, Tivadar Baltazar ${ }^{1}$, Niaz Ahmed ${ }^{10}$ and Martin Brtnicky A, $^{1,2 *^{*}}$

\section{Correction to: Chem Biol Technol Agric (2021) 8:46 https://doi.org/10.1186/s40538-021-00242-7}

Following the publication of the original article [1], the authors identified an error in the affiliation of Dr. Muhammad Nasir.

The correct affiliation is given below:

${ }^{9}$ Soil and Water Testing Laboratory for Research, Multan 60800, Punjab, Pakistan.

The original article [1] has been corrected.

\section{Author details}

'Department of Agrochemistry, Soil Science, Microbiology and Plant Nutrition, Faculty of Agrisciences, Mendel University in Brno, Zemedelska 1, 61300 Brno, Czech Republic. ${ }^{2}$ Department of Geology and Soil Science, Faculty of Forestry and Wood Technology, Mendel University in Brno, Zemedelska 3, 61300 Brno, Czech Republic. Institute of Chemistry and Technology of Environmental Protection, Faculty of Chemistry, Brno University of Technology, Purkynova 118, 61200 Brno, Czech Republic. ${ }^{4}$ Department of Chemistry and Biochemistry, Mendel University in Brno, Zemedelska 1, 61300 Brno, Czech Republic.
${ }^{5}$ Agricultural Research, Ltd, Zahradni 400/1, 66441 Troubsko, Czech Republic ${ }^{6}$ Institute of Environmental Engineering, Warsaw University of Life Sciences, Nowoursynowska 159, 02-776 Warsaw, Poland. ${ }^{7}$ Soil and Water Testing Laboratory for Research, Lahore 54000, Punjab, Pakistan. ${ }^{8}$ Department of Environmental Biotechnology, Faculty of Geoengineering, University of Warmia and Mazury in Olsztyn, Słoneczna St. 45G, 10-719 Olsztyn, Poland. ${ }^{9}$ Soil and Water Testing Laboratory for Research, Multan 60800, Punjab, Pakistan. ${ }^{10}$ Department of Soil Science, Faculty of Agricultural Sciences and Technology, Bahauddin Zakariya University, Multan 60800, Punjab, Pakistan.

Published online: 27 October 2021

\section{Reference}

1. Hammerschmiedt T, Holatko J, Pecina V, Huska D, Latal O, Kintl A, Radziemska M, Muhammad S, Gusiatin ZM, Kolackova M, Nasir M. Assessing the potential of biochar aged by humic substances to enhance plant growth and soil biological activity. Chem Biol Technol Agric. 2021;8:46. https://doi.org/10.1186/s40538-021-00242-7.

\section{Publisher's Note}

Springer Nature remains neutral with regard to jurisdictional claims in published maps and institutional affiliations.

The original article can be found online at https://doi.org/10.1186/s40538021-00242-7.

\footnotetext{
*Correspondence: Martin.Brtnicky@seznam.cz

1 Department of Agrochemistry, Soil Science, Microbiology and Plant Nutrition, Faculty of Agrisciences, Mendel University in Brno, Zemedelska 1, 61300 Brno, Czech Republic

Full list of author information is available at the end of the article
}

(c) The Author(s) 2021. Open Access This article is licensed under a Creative Commons Attribution 4.0 International License, which permits use, sharing, adaptation, distribution and reproduction in any medium or format, as long as you give appropriate credit to the original author(s) and the source, provide a link to the Creative Commons licence, and indicate if changes were made. The images or other third party material in this article are included in the article's Creative Commons licence, unless indicated otherwise in a credit line to the material. If material is not included in the article's Creative Commons licence and your intended use is not permitted by statutory regulation or exceeds the permitted use, you will need to obtain permission directly from the copyright holder. To view a copy of this licence, visit http://creativecommons.org/licenses/by/4.0/. The Creative Commons Public Domain Dedication waiver (http//creativecommons.org/publicdomain/zero/1.0/) applies to the data made available in this article, unless otherwise stated in a credit line to the data. 